\title{
POTENTIALS OF IMPLEMENTATION OF SHARIA PRINCIPLES IN THE TOURISM SECTOR OF BATU CITY EAST JAVA
}

\author{
${ }^{1}$ Irham Zaki, ${ }^{2}$ Gautsi Hamida, ${ }^{3}$ Eko Fajar Cahyono \\ ${ }^{123}$ Department of Islamic Economics-Faculty of Economics and Business-Airlangga \\ University \\ Jl. Airlangga No.4, Airlangga, Kec. Gubeng, Kota SBY, Jawa Timur 60286 \\ 1irham-z@feb.unair.ac.id, ${ }^{2}$ gautsi.hamida-2015@feb.unair.ac.id 3 ekofajarc@feb.unair.ac.id
}

\begin{abstract}
The main objective of this research is to see the potential that supports the implementation of sharia principles in the Batu City tourism sector. The tourism sector studied consists of hotels, restaurants and food, travel agencies and tourist areas. The next objective is to see the economic benefits that will be produced in the future with the application of sharia principles in the tourism sector. This study uses descriptive qualitative methods conducted by interviews, observations and questionnaire tools to see the response generated through a Likert scale. The results of this study indicate that parties related to the tourism sector provide a positive response to the application of sharia principles in the tourism sector, which will provide economic benefits for industry players, the public, and the government.
\end{abstract}

Keywords: Sharia Principles, Halal Tourism, Income, Economic Benefits, Sharia Touris

\section{Introduction}

Islamic economics provide the widest possible opportunity for humans to obtain sources of income from various sources, from industry, trade, and other economic sectors to meet their needs. There are seven sectors of the Islamic economy that have experienced a significant increase, namely culinary, Islamic finance, the insurance industry, fashion, cosmetics, pharmaceuticals, and tourism. In each of its products, the entire sector carries the concept of halal as a way to optimize development Islamic economics (Andriani et al., 2015).

During this sharia tourism is perceived as a tour to the grave (pilgrimage) or to the mosque. In fact, sharia tourism should not only be interpreted as such, but tourism, in which there is nature, culture, or artificial, that is shared with Islamic values (Andriani et al., 2015). The development of sharia tourism or halal tourism has become an alternative for the tourism industry in Indonesia in line with the trend of the halal tourism industry as part of the global Islamic economy (Samori, Salleh, \& Khalid, 2016: 132). Islam has encouraged humanity to travel according to the Word of God in the Qur'an Surah Al Ankabut Verse 20

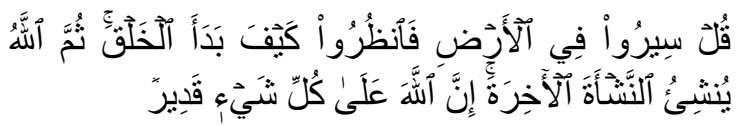

Say, [O Muhammad], "Travel through the land and observe how He began creation. Then Allah will produce the final creation. Indeed Allah, over all things, is competent."

God cited the prophets as a good example for humans. In the Qur'an it is told that the prophets traveled in receiving and

Received: 2019-10-29 | Reviced: 2020-01-03 | Accepted: 2020-01-31

Indexed : Sinta, DOAJ, Garuda, Crossref, Google Scholar | DOI: https://doi.org/10.29313/amwaluna.v4i1.5294 
spreading revelations. As written in Surah Al Kahf Verse 62

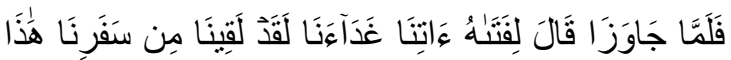

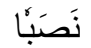

So when they had passed beyond it, [Moses] said to his boy, "Bring us our morning meal. We have certainly suffered in this, our journey, [much] fatigue."

Then the Koran also recognizes that "travel" is an important part of human life. During the time of the Prophet (PBUH) the merchants traveled trade for their businesses. This is enshrined in the Quraish verse verse 2

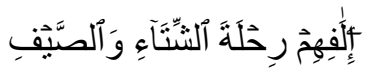

Their accustomed security [in] the caravan of winter and summer-

The command to travel has a purpose so that humans can seek gifts from God. This purpose is explained in the Qur'an Al Mulk verse 15

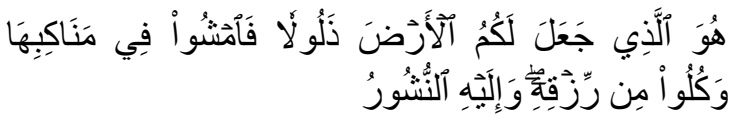

It is He who made the earth tame for you so walk among its slopes and eat of His provision - and to Him is the resurrection.

One of the lessons contained in travel activities is that humans can see the situation and conditions of people in different areas. That vision makes knowledge and experience useful to humans. This has been confirmed in Surah Muhammad verse 10 and Surah Yusuf verse 109 .

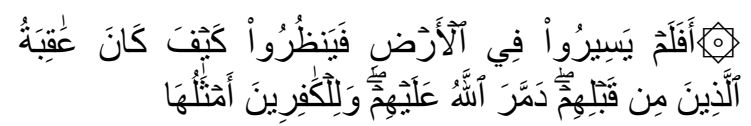

Have they not traveled through the land and seen how was the end of those before them? Allah destroyed [everything] over them, and for the disbelievers is something comparable.

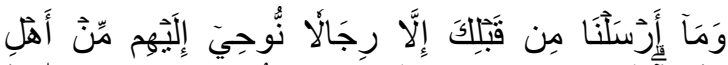

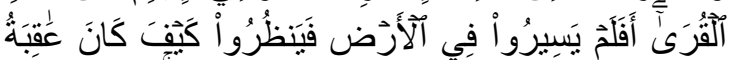

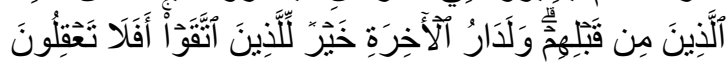

And We sent not before you [as messengers] except men to whom We revealed from among the people of cities. So have they not traveled through the earth and observed how was the end of those before them? And the home of the Hereafter is best for those who fear Allah; then will you not reason?

One of the cities that is famous as a tourism city is Batu City, East Java. The majority of the Muslim population in Batu is one contributing factor to maintain Islamic principles implementation in the sectors of tourism Batu. According to BPS data for 2018, Batu City is a city with a Muslim majority population with a population of 209,479 people (batkot.bps.go.id, 2018). Cultural characteristic of the people of Batu City is known to be religious, influenced by Islamic norms. Islamic studies are often held to improve the religiosity of people in Batu City. Batu City, which includes natural attractions, cultural tourism, and artificial tourism, never lacks in visitors. This means that the economic benefits that will be generated by the Batu City's tourism sector will help to increase Regional Original Income and regional economy.

Conflict in the construction of the BNS (Batu Night Spectacular) also proves that the people of Batu City pay attention to the positive and negative impacts of religious elements in the development of a tourist area. Residents of the Orooro ombo area 
Irham Zaki, Gautsi Hamida, Eko Fajar Cahyono, Potentials Of Implementation Of Sharia.....

reject the construction of one of the famous night tours with various exciting game rides. The community considers that the development of the tourist area labeled sharia principles in its tourism sector (Batu City Tourism Office, 2018).

Policies for implementation - maintain the principles of sharia in the sector of tourism in Batu should be studied further because seeing the many potential from Batu city were very supportive. Provision of tourism based on sharia values is one of the special
"Night Entertainment" will cause a lot of immorality in the city of Batu. From the conflict it can be seen that Batu City can make policies by implementing needs in enhancing religious values in Batu City tourism so that people get blessings for the community, and guarantee the benefit of tourists. Based on the above, it can be formulated as the objective this study is to determine the potential maintain Islamic principles in the tourism sector in Batu city.

\section{Discussion}

Table 1 Definition of Islamic Tourism, Sharia Tourism, Halal Tourism

\begin{tabular}{|l|l|}
\hline Author & Definition \\
\hline $\begin{array}{l}\text { Islamic Tourism Center - Malaysia } \\
\text { (2015) }\end{array}$ & $\begin{array}{l}\text { Any activity, event and experience undertaken in a } \\
\text { state of travel that is in accordance with Islam }\end{array}$ \\
\hline Ala-Hamarneh (2011) & $\begin{array}{l}\text { An economic, cultural and religious } \\
\text { (conservative) concept }\end{array}$ \\
\hline Duman (2011) & $\begin{array}{l}\text { All tourism activities by Muslims that originate } \\
\text { from Islamic motivations and are realized } \\
\text { according to Sharia principles. }\end{array}$ \\
\hline Henderson (2010) & $\begin{array}{l}\text { All product development and marketing efforts are } \\
\text { designed for and directed at Muslims }\end{array}$ \\
\hline Hassan (2007) & $\begin{array}{l}\text { The type of tourism that adheres to the values of } \\
\text { Islam }\end{array}$ \\
\hline All forms of tourism except those that go against \\
Islamic values.
\end{tabular}

Source: Egypt H. El-Gohary: 2016

Definition of potential, according to Myles Monroe (2011) is a capability that is large enough to be but these capabilities are not exposed or exposed but not yet implemented.

Tourism is a journey as an economic phenomenon in its industrial activities is able to improve economic prosperity for related parties and its surroundings.
Tourism comes from Sanskrit language that is pure $=$ perfect, complete, highest, and visat=travel, so that torism can be interpreted as a perfect or complete trip (Arjana, 2015).

Based on data from the MasterCard and Crescent Rating (2015) Indonesia is a member of the OIC (Organization of Islamic Cooperation) and is the 6th ranked country that is the largest visitor 
contributor to sharia tourism in the world (SESRIC, 2017: 10). The following table shows the top 10 Islamic tourism destinations of OIC member countries in
2015 which shows that Indonesia Indonesia participated in developing tourism in the Islamic World as well.

Table 2. Top 10 Islamic Tourism Destinations OIC Member Countries 2015

\begin{tabular}{|c|c|c|}
\hline GMTI 2015 Rank & OIC Destination & Score \\
\hline 1 & Malaysia & 83.8 \\
\hline 2 & Turkey & 73.8 \\
\hline 3 & United Arab Emirates & 72.1 \\
\hline 4. & Saudi Arabia & 71.3 \\
\hline 5 & Qatar & 68.2 \\
\hline 6 & Indonesia & 67.5 \\
\hline 7 & Oman & 66.7 \\
\hline 8 & Jordan & 66.4 \\
\hline 9 & Morocco & 64.4 \\
\hline 10 & Brunei & 64.3 \\
\hline
\end{tabular}

Source: (Master Card and Crescent Rating (2015) (Reuteur: 2016)

To explain the statistic on the table above, according to the results GMTI (Global Muslim Travel Index) in 2015, Malaysia received the first rank with a cumulative score of 83,8 . Indonesia's rating was sixth with a cumulative score of 67,5 . While in the last position, there is Brunei with a rating of 64,3 . Nine of the global top-10 Islamic tourist destinations are members of the OIC (Organization of Islamic Cooperation). Bearing in mind that OIC countries have a comparative advantage because they have a halal and Muslimfriendly environment.

The economic concept for Islamic tourism focuses on the entry of new tourism markets and tourist destinations. This concept is the most widely discussed and understood in Islamic and non- Islamic countries. The tourism industry players consider Muslim countries as one of the new tourism markets with a large economic potential that will be generated in the future. The development of sharia tourism or halal tourism is an alternative for the tourism industry in Indonesia, in line with the trend of the halal tourism industry as part of the global Islamic economy (Samori, Salleh, \& Khalid, 2016: 132).

Sharia tourism is divided into several components, including, Islamic hotels, Islamic travel agencies, halal restaurants, and Islamic tourism objects. According to Chookaew (2015: 740) Sharia hotels are hotels that provide services to Muslim tourists who are not limited to only providing halal food and drinks, but hotel operations and management are also run with the principle of my Sami. Fulfillment of condition of the hotel that kosher also requires that food and drink provided does not serve alcohol and only serve halal food, and emphasized for have halal certification; the existence of Muslim prayer room that accommodates muslims to accomplish their prayers, but it must also contained the Koran and prayer mats and Qiblah direction in each room; the entertainment provided must be 
appropriate i.e. not in bars, casinos and nightclubs; each Muslim employees must wear clothes that conform with Islamic ethics As well as cooperating with the Islamic financial institutions (Puad et al ., 2016) .

Halal restaurants are restaurants that provide halal food and drinks. Halal food is type of foods that are allowed to be consumed by Muslims to Islamic sharia based on the Koran and the Hadith (Marzuki et al ., 2014). Food and drinks that are allowed for Muslims are not only halal but also good for consumption. According to the Indonesian Ulema Council Fatwa Commission, in a joint meeting of the LP POM MUI, on Wednesday, 13 Muharram 1431 H / 30 December 2009 AD, the following provisions regarding the provisions of halal food are:

1. Must be considered and believed to be halal and and pure;

2. Food, drink, is Food and drinks are processed through a way that is undoubtedly halal or pure;

3. Went through the process of examination, research, discussion, and vote by Fatwa Committee.

Sharia Travel Bureau (BPWS) is a commercial business activity that regulates, and provides services for a person or group of people, to travel with the main purpose of traveling in accordance with sharia principles (National Sharia Council FatwaIndonesian Ulema Council NO: 108 / DSN-MUI / X / 2016).

There are several characteristics that explain that tourism is sharia. According to the Ministry of Tourism and Creative Economy and BPH DSN MUI, sharia travel have common criteria as follows (Sofyan 2012: 58) :

1. Oriented to general benefit;

2. Oriented to enlightenment, refreshment, and calmness;

3. Avoiding immorality, such as adultery, pornography, porno-action, liquor, drugs, and gambling;

4. Condemning hedonic and immoral behavior;

5. Maintaining trust, safety and comfort;

6. Universal and inclusive;

7. Protecting the environment;

8. Respecting local cultural values and wisdom;

Sharia principles are rules or agreement in carrying out all things based on the Qur'an and Hadith in accordance with Islamic law and does not violate anything that is forbidden. Nature tourism should avoid activities that involves the following elements: Polytheism; Disobedience; Tabdzir/Israf Interpretation; Munkar (Fatwa of the National Sharia CouncilIndonesian Ulema Council No: 108 / DSN-MUI / X / 2016) .

Based on the World Travel \& Tourism Council (WTTC) in 2004, the tourism sector has had a positive impact on a country's economy. These positive impacts include :

1) Increase revenue for good causes or zakah.

2) Increase employment opportunities. 
3) Contribute directly to the Gross Domestic Product (GDP).

4) Increase investment and exports.

(Joeti. 2008: 19)

Tourism development has a significant impact, both due to increased Original Local Government Revenue and investment in the regional development process. For local people, an increase in income from the tourism sector gives more influence to their life, because it opens up wider employment opportunities. For investors, this policy benefits them because the government gave access and ease to open new business opportunities in tourism sector activities.

This study is based from a study by Chookaew (2015), with an objective to examine the potential in developing into halal tourism. Qualitative approach with Interview techniques, questionnaires, observations and focus group discussions.

This research approach uses a descriptive qualitative research approach. This short note is used to explain perceptions regarding the implementation of sharia principles in the tourism sector in Batu City. This study aims to look at perceptions so that apart from conducting interviews and observations, it is also assisted with a questionnaire tool that uses a Likert scale technique.

The scope of this research only covers the area of Batu City, East Java. In Batu City, a study was conducted at the Batu City Tourism Office, PHRI (Indonesian Hotels and Restaurants Association) and direct observation of the East Java Park Group as an artificial tour with Sky Park as a nature tour. The scope of this study is limited to the potential of Islamic principles, implemented in the tourism sector in Batu.

The type of data source in this study primary data (primary) and secondary (supporting). Primary data obtained through interviews and observations and questionnaire aids. While the secondary data come from previous studies which are in the form of archives of documents, photographs. Data Analysis Research Techniques were use data analysis techniques by Miles and Huberman in Sugiyono (2012: 247-253) explains that there are three techniques of analysis, namely data reduction (reduction of data), the data display (presentation of data) and conclusion drawing (drawing conclusions). The data analysis technique used is the technical analysis of the Miles and Huberman model.

This research uses the source triangulation technique and the technique triangulation, which is done by testing the data by checking the data obtained from different informants and through different techniques. The existence of these methods may be compared to the harmony between the interview with the Head of the Product Development Department of Tourism, Head of Tourism, Chairman of IHRA, Manager of Marketing and Public Relations East Java Park Group, and Public Relations and Marketing Sky Park also conducted an analysis of the alignment between the interviews, documentation, observation and the results of tourist perceptions through the help of questionnaires.

Data collection procedures are some data collection techniques. Has been explained by Yin (2014: 103) data collection techniques, namely interviews, 
Irham Zaki, Gautsi Hamida, Eko Fajar Cahyono, Potentials Of Implementation Of Sharia.....

documentation, direct observation, archival records, and physical devices. Data collection techniques used in this study are:

\section{Interview}

The structured interview method is carried out. For this reason, it has been prepared. Some questions related to the topic to be researched in writing. Interviews were conducted with the Department of Tourism, PHRI, and industry players with questionnaire aids distributed to 50 domestic and foreign tourists.

\section{Documentation}

Methods of documentation done by collecting data on issues or variables in the form of notes, transcripts, books, letters, newspapers, magazines, meeting minutes, agenda, data on impressions and visitor messages via the internet and so on.

\section{Observation}

Observable activities are carried out by recording principally to manipulate events, behaviours, objects seen and other things needed to support research. The results of these observations are collected as much as possible and then narrowed so that it can be found patterns of behaviour and relationships that constantly occur (Sarwono, 2006: 224).

\section{Likert Scale questionnaire}

Qualitative research can be supported by distributing questionnaires. Supporting data was obtained by distributing questionnaires using a Likert scale technique to see the perceptions of 50 tourists in Batu, both domestic and foreign, selected to support the interview data regarding the potential the application of the sharia system in tourism in Batu. The scoring technique used in this research questionnaire is the Likert scale technique. Likert scale is used as a support to determine the perception of tourists. Likert scale according to Sugiyono (2013: 132) is "Likert scale used to find out the attitudes, opinions and perceptions of a person or group people about social phenomena ". Each answer choice on the Likert scale is given a score. The answer score is the value of the answer that will be given by the respondent. According to Sugiyono (2013), the first thing to do is determine the score of each answer that will be given. The use of Likert scale in this study can be seen in the table 3

Table 3 Valuation of Likert Scale

\begin{tabular}{|l|l|}
\hline Answers Scale & Value \\
\hline $\begin{array}{l}\text { Very Strongly } \\
\text { Disagree }\end{array}$ & 1 \\
\hline Strongly Diasgree & 2 \\
\hline Neutral & 3 \\
\hline Agree & 4 \\
\hline Strongly Agree & 1 \\
\hline
\end{tabular}

Source : Sugiyono, 2012

As for the calculation using a Likert scale quoting from Nazir(2005), the Likert scale calculation uses the formula below:

$$
\begin{aligned}
& \text { Formula }=T \times P n \\
& \mathrm{~T}=\text { Total Respondent }
\end{aligned}
$$

$$
\text { Pn }=\text { Likert Score chosen by Respondent }
$$

As for the interpretation of the calculation score, in order to get resultsinterpretation, the highest score (X) and the lowest score

(Y) must be known first for valuation items with the following formula:

$\mathrm{Y}=$ highest score Likert $\mathrm{x}$ number of respondents 
$\mathrm{X}=$ lowest score Likert $\mathrm{x}$ number of respondents

Index Formula

$$
\%=\frac{\text { Score Total }}{Y \times 100}
$$

Before completing it, the interval must also be known know the assessment.

$$
\text { Interval Formula I }=\frac{100}{\text { Score Total }}
$$

This is the interval from the lowest $0 \%$ to the highest $100 \%$ ) In order to know the perceptions of tourists can be seen from the interpretation of the scorebased on the interval. From this interval it can be seen the perception of tourists, thatourists strongly agree, agree, neutral, disagree and strongly disagree. Following a table regarding the criteria for interpreting scores based on intervals can be seen in the table 4

Table 4 Likert Scale Interval

\begin{tabular}{|l|l|}
\hline Score & Answers Scale \\
\hline $0 \%-19.99 \%$ & Strongly Disagree \\
\hline $20 \%-39.9 \%$ & Disagree \\
\hline $40 \%-59.9 \%$ & Neutral \\
\hline $60 \%-79,99 \%$ & Agree \\
\hline $80 \%-100 \%$ & Stronly Agree \\
\hline
\end{tabular}

Source : Nazir ,2005
Then the final settlement is done with the final settlement below:

$$
\text { Final Settlemnet }=\frac{\text { Total Score }}{Y \times 100} \ldots
$$

The final settlement results can be matched with the interval scores in table 4 , so that tourists can perceive. With the help of useLikert scale can help get answers about from tourists regarding the potential application of the sharia system in Batu City tourism.

\section{Batu Tourism City}

Batu City, a city located in the northwest of Malang, East Java, has four main development area functions including agriculture, horticulture, services, and tourism That causes the tourism sector to have an influence in increasing the income of the Batu City area. Especially with the development of tourism by implementing the principles of sharia.

Perception of tourists as users of travel agency services is needed to support the implementation of Islamic travel agencies in Batu City. Following is a table 5 regarding the perceptions of tourists

\begin{tabular}{|c|c|c|c|c|c|c|c|c|}
\hline \multirow{2}{*}{$\begin{array}{l}\mathrm{N} \\
\mathrm{O}\end{array}$} & \multirow{2}{*}{$\begin{array}{l}\text { Halal Tourism Component on } \\
\text { Travel Agents }\end{array}$} & \multicolumn{5}{|c|}{ Tourist Answers Frequency and Percentage } & \multirow{2}{*}{$\begin{array}{l}\text { Likert } \\
\text { Score }\end{array}$} & \multirow[t]{2}{*}{ Category } \\
\hline & & $\begin{array}{l}\text { Strongly } \\
\text { Agree }\end{array}$ & Agree & Neutral & Disagree & $\begin{array}{l}\text { Strongly } \\
\text { Disagree }\end{array}$ & & \\
\hline 1 & $\begin{array}{l}\text { I feel comfortable with the } \\
\text { availability of tour packages that } \\
\text { are in accordance with Islamic } \\
\text { principles }\end{array}$ & $9 / 18 \%$ & $\begin{array}{l}33 / \\
66 \%\end{array}$ & $4 / 8 \%$ & $4 / 8 \%$ & $0 / 0 \%$ & 78.8 & Agree \\
\hline 2 & $\begin{array}{l}\text { I will choose a bureau that will } \\
\text { set aside time to pray } 5 \text { times in } \\
\text { between activities }\end{array}$ & $5 / 10 \%$ & $\begin{array}{l}34 / \\
68 \%\end{array}$ & $\begin{array}{ll}7 / 14 \\
\%\end{array}$ & $4 / 8 \%$ & $0 / 0 \%$ & 76 & Agree \\
\hline 3 & $\begin{array}{l}\text { I will choose a bureau that offers } \\
\text { safe and halal food menu } \\
\text { offerings to tourists }\end{array}$ & $14 / 28 \%$ & $\begin{array}{l}30 \% \\
60 \%\end{array}$ & $\begin{array}{ll}5 / 10 \\
\%\end{array}$ & $1 / 2 \%$ & $0 / 0 \%$ & 82.8 & $\begin{array}{l}\text { Strongly } \\
\text { Agree }\end{array}$ \\
\hline
\end{tabular}
regarding travel agents Batu City.

Table 5 .Tourist Perception on Halal Tourism Component on Travel Agents 
Irham Zaki, Gautsi Hamida, Eko Fajar Cahyono, Potentials Of Implementation Of Sharia.....

\begin{tabular}{|l|l|l|l|l|l|l|l|l|l|}
\hline 4 & $\begin{array}{l}\text { I often use the services of a tour } \\
\text { and travel agent }\end{array}$ & $9 / 18 \%$ & $\begin{array}{l}29 / \\
58 \%\end{array}$ & $\begin{array}{l}6 / 12 \\
\%\end{array}$ & $6 / 12 \%$ & $0 / 0 \%$ & 76.4 & Agree \\
\hline
\end{tabular}

Source: Authors own

The numbers in the table 5 are obtained from Likert scale scores obtained from respondents' answers. It can be seen the opinions of 50 visitors to the Batu City tour who were randomly assigned respondents. In accordance with the results of the interval valuation it shows that the classified respondents' statements strongly agree (a statement) in the group statement 3 and agree (three statements) in the group statements 1,2 and 4. Table 6 shows that tourists feel safe in conducting tourism

activities in Batu City if the travel agency in Batu City offers services in accordance with sharia principles.

Perception of tourists is needed to support the application of the sharia system in hotel hospitality. Following are the perceptions of tourists and the public about the application of the sharia system to hospitality and the conditions of hospitality in Batu City, as shown in table 6 below

Table 6.Tourist Perception on Hotel

\begin{tabular}{|c|c|c|c|c|c|c|c|c|}
\hline \multirow{2}{*}{$\begin{array}{l}\mathrm{N} \\
\mathrm{O}\end{array}$} & \multirow{2}{*}{$\begin{array}{l}\text { Halal Tourism Component } \\
\text { on Hotel }\end{array}$} & \multicolumn{5}{|c|}{ Tourist Answers Frequency and Percentage } & \multirow{2}{*}{$\begin{array}{l}\text { Likert } \\
\text { Score }\end{array}$} & \multirow[t]{2}{*}{ Category } \\
\hline & & $\begin{array}{l}\text { Strongly } \\
\text { Agree }\end{array}$ & Agree & Neutral & Disagree & $\begin{array}{l}\text { Strongly } \\
\text { Disagree }\end{array}$ & & \\
\hline 1 . & $\begin{array}{l}\text { I know I often use the } \\
\text { services of a tour and } \\
\text { travel agent }\end{array}$ & $7 / 14 \%$ & $\begin{array}{l}32 \% \\
64 \%\end{array}$ & $\begin{array}{ll}8 / 16 \\
\%\end{array}$ & $3 / 6 \%$ & $0 / 0 \%$ & 72 & Agree \\
\hline 2 & $\begin{array}{l}\text { I find hotels that are } \\
\text { Muslim-friendly and } \\
\text { available facilities of } \\
\text { worship around attractions } \\
\text { easily }\end{array}$ & $6 / 12 \%$ & $\begin{array}{l}32 / \\
64 \%\end{array}$ & $\begin{array}{l}10 / 20 \\
\%\end{array}$ & $2 / 4 \%$ & $0 / 0 \%$ & & \\
\hline 3 & $\begin{array}{l}\text { I feel hotel atmosphere in } \\
\text { Batu City is safe, } \\
\text { comfortable } \\
\text { conducive to and } \\
\text { immorality and liquor } \\
\text { sales }\end{array}$ & $5 / 10 \%$ & $\begin{array}{l}34 / \\
68 \%\end{array}$ & $\begin{array}{ll}9 / 18 \\
\%\end{array}$ & $2 / 4 \%$ & $0 / 0 \%$ & 76.8 & Agree \\
\hline 4 & $\begin{array}{l}\text { I feel at home with hotel } \\
\text { services in Batu City }\end{array}$ & $9 / 18 \%$ & $\begin{array}{l}33 / \\
66 \%\end{array}$ & $\begin{array}{lll}8 / 16 \\
\%\end{array}$ & $0 / 0 \%$ & $0 / 0 \%$ & 80,4 & $\begin{array}{l}\text { Storngly } \\
\text { Agree }\end{array}$ \\
\hline
\end{tabular}

Source: Authors own

The numbers in the table above are obtained from Likert scale scores obtained from respondents' answers. Based on the table 6, it can be seen the opinions of 50 Batu City tourist visitors who were respondents. In accordance with the results of the validation that has been, it shows that the classified respondents' statements strongly agree (a statement) in the statement group 4 and agree (three statements) in the statement group 1,2 , and
3. Table 6 shows that tourists give a positive response to hospitality services in Batu City and feel comfortable with the condition of the facilities and infrastructure provided by hospitality in Batu City, as can be seen that the hotel has maintained normative sharia rules such as avoiding immoral activities, and selling alcohol drink. 
Perception of tourists is needed to see whether restaurants provide halal foods and drinks matters to them. To see the perceptions of tourists about the condition of restaurants in Kota Batu, it can be seen in table 7.

Table 7. Tourist Perception on Restaurant

\begin{tabular}{|c|c|c|c|c|c|c|c|c|}
\hline $\mathrm{N}$ & Halal & Tourist $\mathrm{Al}$ & wers Fr & quency ar & d Percenta & & Likert & Category \\
\hline $\mathrm{O}$ & $\begin{array}{l}\text { Component on } \\
\text { Resturant }\end{array}$ & $\begin{array}{l}\text { Strongly } \\
\text { Agree }\end{array}$ & Agree & Neutral & Disagree & $\begin{array}{l}\text { Strongly } \\
\text { Disagree }\end{array}$ & Score & \\
\hline 1 & $\begin{array}{l}\text { I always pay attention } \\
\text { to the halalness of the } \\
\text { food menu that is } \\
\text { presented by tourism } \\
\text { objects }\end{array}$ & $6 / 12 \%$ & $\begin{array}{l}331 \\
66 \%\end{array}$ & $\begin{array}{lll}5 & / 10 \\
\% & \end{array}$ & $5 / 10 \%$ & $0 / 0$ & 76 & Agree \\
\hline 2 & $\begin{array}{l}\text { I find restaurants that } \\
\text { sell halal food in Batu } \\
\text { City easily }\end{array}$ & $10 / 20 \%$ & $\begin{array}{l}34 \quad / \\
68 \%\end{array}$ & $\begin{array}{lll}5 & / 10 \\
\% & \end{array}$ & $1 / 2 \%$ & $00 \%$ & 81,2 & $\begin{array}{l}\text { Strongy } \\
\text { Agree }\end{array}$ \\
\hline 3 & $\begin{array}{l}\text { I always ensure halal } \\
\text { products sold in } \\
\text { restaurants or centers } \\
\text { by when traveling }\end{array}$ & $6 / 12 \%$ & $\begin{array}{l}321 \\
64 \%\end{array}$ & $\begin{array}{lll}5 & / 10 \\
\% & \end{array}$ & $1 / 2 \%$ & $0 / 0 \%$ & 76 & Agree \\
\hline 4 & $\begin{array}{l}\text { My buying interest is } \\
\text { influenced by halal } \\
\text { labels }\end{array}$ & $6 / 12 \%$ & $\begin{array}{l}30 \% \\
60 \%\end{array}$ & $\begin{array}{lll}7 & / & 14 \\
\% & \end{array}$ & $7 / 14 \%$ & $0 /) 5$ & 74 & Agree \\
\hline
\end{tabular}

Source: Authors own

The numbers in table 7 are obtained from the Likert scale score obtained from the respondent's answer. Based on the table above, it can be seen the opinions of 50 Batu City tourist visitors who were respondents. In accordance with the results of the interval valuation, it shows that the classified respondent's statement strongly agreed (a statement) in the statement group 2 and agreed (three statements) in the statement groups 1,3 , and 4 . Table 7 shows that tourists pay attention to the halal food in carrying out their consumption activities and shows the ease of tourists in obtaining halal food in the Batu City area.

Perceptions of tourists is also used to see the role of tourism on the economy. Important role on the economy felt like the development of MSMEs, an increase employment opportunities, increased income generation for business owners. The following table 8 which contains the perceptions of tourists

Table 8. Perception on Role Halal Tourism on Economic Development

\begin{tabular}{|c|c|c|c|c|c|c|c|c|}
\hline $\mathrm{N}$ & Role Halal Tourism on & Tourist A & wers Fr & quency as & d Percenta & & Likert & Category \\
\hline $\mathrm{O}$ & $\begin{array}{l}\text { Economic } \\
\text { Development }\end{array}$ & $\begin{array}{l}\text { Strongly } \\
\text { Agree }\end{array}$ & Agree & Neutral & Disagree & $\begin{array}{l}\text { Strongly } \\
\text { Disagree }\end{array}$ & Score & \\
\hline 1 & $\begin{array}{l}\text { Tourism that maintains } \\
\text { Islamic rules will } \\
\text { benefit } \\
\text { growth }\end{array}$ & $9 / 18 \%$ & $\begin{array}{l}35 \quad / \\
70 \%\end{array}$ & $4 / 8 \%$ & $2 / 4 \%$ & $0 / 0 \%$ & 80.4 & $\begin{array}{l}\text { Strongly } \\
\text { Agree }\end{array}$ \\
\hline 2 & $\begin{array}{l}\text { Tourism that maintains } \\
\text { Islamic principles will } \\
\text { increase the interest of } \\
\text { tourists and investors }\end{array}$ & $10 / 20 \%$ & $\begin{array}{l}31 / \\
62 \%\end{array}$ & $\begin{array}{ll}7 / 14 \\
\%\end{array}$ & $2 / 4 \%$ & $0 / 0 \%$ & 79,6 & Agree \\
\hline 3 & Tourism that maintains & $9 / 18 \%$ & 28 & $12 / 24$ & $1 / 2 \%$ & $0 / 0 \%$ & 78 & Agree \\
\hline
\end{tabular}


Irham Zaki, Gautsi Hamida, Eko Fajar Cahyono, Potentials Of Implementation Of Sharia.....

\begin{tabular}{|c|c|c|c|c|c|c|c|c|}
\hline & $\begin{array}{l}\text { Islamic principles will } \\
\text { help improve people's } \\
\text { welfare }\end{array}$ & & $56 \%$ & $\%$ & & & & \\
\hline 4 & $\begin{array}{l}\text { Like travel that is safe, } \\
\text { lawful and in } \\
\text { accordance } \\
\text { Islamic rules }\end{array}$ & $3 / 6 \%$ & $\begin{array}{l}32 \quad 1 \\
64 \%\end{array}$ & $\begin{array}{lll}9 & / & 18 \\
\% & \end{array}$ & $6 / 12 \%$ & $0 / 0 \%$ & 72.8 & Agree \\
\hline 5 & $\begin{array}{l}\text { Do not mind spending } \\
\text { money to enjoy } \\
\text { attractions that are } \\
\text { managed based on } \\
\text { Islamic values }\end{array}$ & $8 / 16 \%$ & $\begin{array}{ll}28 \quad / \\
56 \%\end{array}$ & $\begin{array}{l}10 / 20 \\
\%\end{array}$ & $4 / 8 \%$ & $0 / 0 \%$ & 76 & Agree \\
\hline 6 & $\begin{array}{l}\text { The existence of } \\
\text { sharia-compliant } \\
\text { tourism will help drive } \\
\text { the Islamic economy }\end{array}$ & $8 / 16 \%$ & $\begin{array}{l}28 \quad / \\
56 \%\end{array}$ & $\begin{array}{l}10 / 20 \\
\%\end{array}$ & $4 / 8 \%$ & $0 / 0$ & 76 & Agree \\
\hline
\end{tabular}

Source: Authors own

The numbers in the table 8 are obtained from the Likert scale score obtained from respondents' answers. Can be seen the opinions of 50 tourist visitors Batu City is the respondent. In accordance with the results of the interval, it shows that the respondent's statement classified strongly agree (a statement) on group statements 1 and agree (three statements) in the statement group 2,3,4,5 and 6. Table 8 shows that tourists feel if tourism in Batu City is implementing sharia system in tourism, it will provide benefits economical for Batu City.

Table 9. Summary of Analysis Results

\begin{tabular}{|l|l|l|l|}
\hline $\begin{array}{l}\text { N } \\
\text { o }\end{array}$ & Domain & Sub-Domain & $\begin{array}{l}\text { Conclusion/ } \\
\text { Explanation }\end{array}$ \\
\hline 1 & Potency & & $\begin{array}{l}\text { The Tourism Office, PHRI, industry players, and tourists support and declare } \\
\text { halal / sharia tourism deemed beneficial and potential. }\end{array}$ \\
\hline & & Hotel & $\begin{array}{l}\text { Support the principles of sharia implementation with the availability of } \\
\text { facilities for worship and avoid immoral }\end{array}$ \\
\hline & & Restaurant & Support by providing food and beverages are kosher \\
\hline & & Travel agency & Support by providing halal travel packages \\
\hline 2 & $\begin{array}{l}\text { Economic } \\
\text { advantage }\end{array}$ & Effort & $\begin{array}{l}\text { Support with the provision of facilities for worship and avoid immoral } \\
\text { activities }\end{array}$ \\
\hline
\end{tabular}

Source: Author processed 
Based on the results of the analysis of the research, several main points of discussion in the research carried out can be drawn, including:

1. The results of the perception of the potential Islamic principles, implemented in the tourism sector in the Batu city.

2. The results of the analysis of the economic benefits of the potential implementation of Islamic principles in the tourism sector in Batu city.

The potential implementation of sharia principles in Batu City is supported by The Ministry Tourism and Creative Economic, Tourism Department, IHRA, Performer Industry and tourists. Batu city's application of principles of sharia as the Department of Tourism has planned and target Batu city to become a halal tourist destination. This statement is supported by some examples such as, the popularity of Batu City in foreign markets (Malaysia, Singapore, Middle East so that it becomes one of the popular tourist destinations in foreign countries, especially for Muslim countries such as Malaysia and the Middle East This is in line with the Word of God based on DSN MUI

Sharia tourism or halal tourism has become one of the trends that exist in the world today. This could be a golden opportunity for Batu if they successfully applied the principles of sharia in the tourism because it can help to improve the national income. According to Spillane (1987). This increase in foreign exchange occurs because tourists will spend their money to meet their needs in travel, accommodation needs, hotels, restaurants and various other services.
The availability of variety and the number of tourist attractions in Batu, which are popular in the eyes of foreign tourists, supports the potential implementation of sharia principles in the tourism of Batu City. The interest of foreign tourists in tourist destinations in Batu City is evidenced by the establishment of cooperation between the Tourism Office and PHRI with tour operators from the Middle East.

Based on the relationship between tourism sector revenue, which in this case is held by the Indonesian Hotel and Restaurant Association (PHRI) with the Regional Original Revenue (PAD), can be concluded that from the increased demand for the implementation of sharia principles in hotel services, there will also be an increase in demand for hotel rooms that booked by tourists will affect the City's income. With the potential presented by the PHRI and the approval of the PHRI for the implementation of sharia principles will provide benefits in the future such as short-term investment and long-term investment.

The restaurant in Kota Batu supports the implementation of sharia principles by maintaining cleanliness, goodness, security and halal of food ingredients. However, restaurants that have halal certificates are still not available in Batu City. Because the process of obtaining halal certificates must go through a long process and the costs are quite high. This potential is also supported by the awareness of Muslims on the importance of halal labels in determining their consumption activities.

The implementation of sharia principles receives support from tourism businesses as seen from the travel agency business 
that is motivated to collaborate with the Middle East. The existence of this collaboration helps Batu City tourism can spread its wings in the world of foreign tourism, especially to be known by Islamic countries.

Maintaining the principle of sharia attractions in Kota Batu also builds will DSN-MUI NO: 108 / DSN-MU / | X / 2016 About Halal Tourism Guideline. In order to be awake from the principles of sharia, tourism must pay attention to the following matters:

1. Avoiding polytheism, disobedience, disobedience, tabdzir, Israf, and munkar;

2. Creating benefits and benefits both materially and spiritually

Based on the MUI DSN Fatwa mentioned above, the fatwa is in line with information obtained through the informants based on the results of the interview.

From the information obtained through informants, the Batu City tourism bureau has carried out its tourism, according to the DSN-MUI Fatwa NO: 108 / DSN-MU / | X / 2016 About Guidelines for Organizing Tourism Based on Sharia Principles. So that the implementation of sharia principles in Batu City Tourism can be said to have proceeded even though it has not been labelled "sharia".

The aim of the Batu City Tourism Office is to increase economic growth; improve people's welfare; eradicate poverty; overcoming the unemployment; preserving nature, environment and resources; promote culture; lift the nation's image; foster a sense of love for the motherland; this is felt to be in line with the objectives of the implementation of sharia principles in tourism.

When sharia principles in each tourism sector is implemented, it will provide economic benefits, namely an increase in the economic welfare of the community through SMEs (Small Medium Enterprises). SMEs, usually a creative industry that processes raw materials produced by the City of Batu so as to bring up new products that have a higher selling value according to the way the materials and products are derived from natural products produced directly in Batu City. When a community empowerment through SMEs can be realized through the implementation of the principles of sharia, then the benefit of society will be achieved.

According to Pratiwi (2014), an increase in Original Revenue in the Regions walks through the number of tourist visits to attractions that will directly contribute to the receipt of the attraction of the attraction itself, so that later it will increase the Original Regional Opinion. The implementation of sharia principles in the tourism of Batu City also triggered cooperation between Batu City and tour operators from the Middle East and OIC member countries. Cooperation will provide economic benefits because there is an attraction for foreign investors to make investment activities in Batu City. Based on interviews and data obtained, the implementation of sharia principles can trigger an increase in the number of foreign and domestic tourists, especially tourists from Muslim countries.

Policies holder such as the Department of Tourism has been committed and are 
working to build its developed halal tourism in Batu. In interviews with the Department of Tourism, IHRA and Doers Industry, and through the results of questionnaires filled out by tourists, who the actors agree if implemented the principles of sharia tourism in Batu City. The benefits felt by industry players, policy makers, and the surrounding community are in line with the statement explained by Yoeti (Yoeti. 2008: 21):

a. Creating opportunities to try to be better. When an area is visited by many tourists, the area will clean up and try to provide various needs and desires of tourists by providing facilities and accommodations that are in accordance with sharia principles.

b. Increase job opportunities. When an area's tourism industry is getting more advanced, naturally, hotels and other complementary facilities will be more and more, and therefore more workforce is needed. As is known, full employment is one of the main objectives of macroeconomic policy. Increasing employment opportunities will direct the region concerned closer to achieving full employment.

c. Increase in government tax revenue and retribution. In accordance with Government Regulations in force every purchase of tourists will be subject to tax. Taxation a partial fiscal policy to income generating with government expenditure.

d. Increase in national income through increasing products and services in one of its sectors. As an increase in products and services by SMEs in Batu City. e. Encourage increased investment from the industrial sector and other economic sectors. With the implementation of sharia principles, the main investment comes from Muslim countries. Implicitly, this increase will encourage economic growth.

\section{Conclusion}

Based on research conducted, it can be concluded that Batu City has the potential to implement sharia principles. The Tourism Office and the IHRA have committed to implementing the principles of sharia in the tourist town of Batu.

Potential implementation of the principles of sharia in tourism can be viewed from a number of factors, namely the implementation of the principles of sharia in the hotel, the implementation of the principles of sharia restaurant and the food is kosher, the implementation of the principles of sharia travel agency, implementing the principles of sharia attraction if the infrastructures are considered to have the potential to implement sharia principles, in addition to infrastructure readiness factors based on interviews with existing sources, related parties related to tourism in Batu City also support the implementation of these sharia principles. Economically, it generates the implementation of the principles of sharia in the tourism Batu City also feel would provide economic benefits such as improving the regional income, leading to new entrepreneurs from SMEs as well as an increasing in the number of foreign tourists in particular for tourists who come from Muslim countries. 
Irham Zaki, Gautsi Hamida, Eko Fajar Cahyono, Potentials Of Implementation Of Sharia.....

\section{Suggestion}

Stake Holder

- Provide a special budget to develop buildings to comply with sharia standards.

- Reproduce socialization, education to the travel industry players, and the conjecture it is tourism that principles of sharia implementation could be realized .

- Make regulations regarding tourism with sharia principles, considering that Batu City is a tourist city .

For Further Researchers

- This research can be used as reference material for further research in subsequent studies.

- This research is still limited in Batu City and has not examined in detail the potential implementation of sharia principles in tourism, it is hoped that it can examine in more detail and in depth in conducting research into the potential implementation of sharia principles in tourism.

- Do more research on the potential implementation of the principles of shari

\section{Bibliograpy}

Andriani, Early . (2015). Sharia Tourism Development Study . Final Report of the 2015 Ministry of Tourism's Tourism and Development Institutional Deputy.

Arjana, I Gus ti Good. (2015). Tourism Geography and Creative Economy .Jakarta: Rajawali Press.

Batkot.bps.go.id
Chookaew, S., Chanin, O., Charatarawat, J., Srip rasert, P., \& Nimpaya, S. (2015). Increasing Halal Tourism Potential at Andaman Gulf. Journal of Economics, Business and Management, III (7), 277-279.

Crescent Rating. (2015). Muslim / Halal Travel Ma rket: Basic Concepts, Terms and Definitions. Singapore ore: Crescent

Rating.

Council of National Sharia-Majelis Ulama Indonesia.(2016). Guidelines for Organizing Tourism Based on Sharia Principles No: 108 / DSN-MUI / X / 2016.

El-Gohary, Egyp t H. (2016). Halal tourism, is it really Halal ? Tourism Management Perspectives 19 (124130). Faculty of Business, Law and Social Sciences. University Busine ss School. Cairo University.

Halim, Abdul. (2004). Regional Financial Management . Yogyakarta

Islah, Muainaul. (2018). The Influence of the Number of Visitors and Returns (Traders) of Sunan Giri Religious Tourism Area on Revenue.

Jonathan, Sarwono. (2006). Methods Quantitative and Qualitative Research. Yogyakarta: Graha Science.

Marzuki, SZS, Hall, CM, \& Ballantine, PW (2014). Measurement of Restaurant Manager Expectations Toward Halal Certification Using Factor and Cluster Analysis . Procedia Social and Behavioral Sciences, Vol. 121

Monroe, Myles. (2011). Purpose For Living . Indonesia: Andi Publisher. 
Ni Lu Ge de, Ana Pratiwi. (2014). The Effect of Tourist Visits, Tourist Attraction Objects and PHR on Regional Original Revenue (PAD) of Gianyar Regency. E-journal Economic development. Vol 3, No.3.

Organization of Islamic Cooperation. (2017) . Statistical, Economic and Social Research and Training Center for Islamic Countries (SESRIC). Strat egic Roadmap For Development Of Islamic Tourism In OIC Member Countries

Puad, Ahmad . (2016). Successful Management of Shariah Compliant Accommodation Sector in Malaysia. World Applied Sciences Journal 34 (12): 1876-1881. Fac ulty of Applied Social Sciences. Sultan Zainal Abidin University , Malaysia. College of Tourism, Rikkyo University, Japan. sp2010.bps.go.id

Samori, Zakiah . (2016). Review of Current Tr ends On Halal Tourism: Cases On
Selected Asian Countries . 19 (2016) 131136. Department of Business Administration. Faculty of Management. Academy of Conte mporary Islamic Studies (ACIS). Malaysia: Universiti T MARA technology

Sugiyono (2012). Met ode Research Quantitative, Qualitative, and $R \& D$. Bandung: Alfabeta.

Sugiyono (2013). Methods Pen upbringing Quantitative Approach, Qualitative and $R \& D$. Bandung: Alfabeta.

Yoeti, Oka A. (2008). Tourism Economics: Industry, Information and Implementation . Jakarta: Kompas.

Yin, Robert K. (2014). Case Study Research Design and Methods ( $5^{\text {th }} \mathrm{ed}$.) Thousand Oaks, CA Sage. 